\title{
Quality Assessment of Some Springs in the Awing Community, Northwest Cameroon, and Their Health Implications
}

\author{
Nelson Alakeh Mofor, ${ }^{1}$ Estella Buleng Tamungang Njoyim, ${ }^{1,2}$ \\ and Antoine David Mvondo-Z $\mathbf{e}^{3}$ \\ ${ }^{1}$ Laboratory of Noxious Chemistry and Environmental Engineering (LANOCHEE), Department of Chemistry, \\ Faculty of Science, University of Dschang, Dschang, Cameroon \\ ${ }^{2}$ Department of Chemistry, Higher Teacher Training College, The University of Bamenda, Bamenda, Cameroon \\ ${ }^{3}$ Laboratory of Soil Analysis and Environmental Chemistry (LASAEC), Department of Soil Science, Faculty of Agronomy and \\ Agricultural Sciences (FAAS), University of Dschang, Dschang, Cameroon \\ Correspondence should be addressed to Estella Buleng Tamungang Njoyim; bulengyim@yahoo.com
}

Received 15 July 2017; Accepted 28 September 2017; Published 8 November 2017

Academic Editor: Davide Vione

Copyright @ 2017 Nelson Alakeh Mofor et al. This is an open access article distributed under the Creative Commons Attribution License, which permits unrestricted use, distribution, and reproduction in any medium, provided the original work is properly cited.

Some springs in Awing, North West Cameroon, were assessed in order to ascertain their quality for human consumption. Achialum, Meupi, and Alaamiti quarters in Awing depend on springs as the major source of drinking water and inhabitants consume it in its natural state without prior assessment and treatment. Water samples were collected from Achialum, Meupi, and Alaamiti and analysed for organoleptic, physicochemical, and bacteriological parameters using standard methods. Results of organoleptic and physicochemical parameters showed that most of the parameters fell below WHO limits. Water quality index results, based on physicochemical parameters only, showed that Achialum and Alaamiti springs were of good quality while Meupi spring was of poor quality. Water quality index may not carry enough information about the real quality situation since a single bad parameter value can give misleading information about the water quality. However, the bacteriological aspect revealed the presence of faecal coliforms and pathogenic bacteria in all the springs that justified the high rate of water borne diseases recorded in the area. This poor water quality could be associated to poor hygiene and farming practices. Thus, the population of Awing should implement home water treatment methods such as boiling, filtration, or chlorination before consumption.

\section{Introduction}

Water is a very important component of life for both plants and animals and it is essential in sustaining life. Improving access to safe drinking water can result in tangible benefits to health. The quality of drinking water has a powerful impact on public health and therefore, the effective monitoring and comprehensive assessment of public or community drinking water systems are crucial to protect the wellbeing of the public [1-5].

The main sources of water are rain water, groundwater (wells, boreholes, and springs) and surface water (rivers, lakes, streams, and oceans). A spring can be described as any natural occurrence where water flows on to the surface of the earth from below underneath. Springs may result from karst topography where surface water has infiltrated into the earth's surface, becoming part of the area's ground water that travels through a network of cracks and fissures ranging from intergranular spaces to large caves. The water eventually emerges from below the surface, in the form of a spring $[6,7]$. Springs are very important elements of the natural environment and respond well to any changes that occur in natural ecosystems, and therefore can be classified as important hydrogeological indicators. In mountainous areas, springs are an important element of groundwater studies [8].

The United Nations Convention on the Rights of the Child stipulates that states and their partners have the obligation to provide clean drinking water to all children [9]. The consumption of water containing pathogenic organisms or toxic chemicals and the use of inadequate volumes of water, 
resulting in poor hygiene, pose serious risks to human health $[4,5]$. In addition, the organoleptic characteristics of water (colour, taste, and odour) might render it unfit for drinking and other uses. For this reason, water quality assessment and continuous monitoring are of utmost importance [4]. National drinking water standards often stipulate the maximum permissible concentration of contaminants in drinking water. In cases where such national standards are not available, the "guidelines for drinking water quality" published by World Health Organization (WHO) is followed [2]. Each value given in the guidelines represents the concentration of a constituent that does not result in any significant health risk to the consumer over a lifetime of consumption.

Water quality assessment provides the base line information on water safety. Since water quality in any source of water and at the point of use can change with time and other factors, continuous monitoring of water is essential. The list of parameters to be tested in any water assessment and monitoring program will vary according to local conditions of the area. Parameters that are basic and generally considered priorities in any water quality assessment include organoleptic parameters, physicochemical parameters, harmful chemicals, and microbiological parameters $[2,9]$.

For water resources to be managed in an effective manner, development should be viewed as an integrated and continuous process for sustainability and poverty reduction [11]. In Awing, treated pipe born water is developed and managed by Ndong Awing Cultural and Development Association (NACDA). The pipe born water supply line does not reach all the quarters in Awing and may be due to the hilly nature of these quarters. Some quarters in Awing such as Achialum, Meupi, and Ala'amiti depend so much on springs as the major source of drinking water. Most inhabitants of these quarters consume this spring water in its natural state without any prior treatment as it appears clean upon viewing. But data from the Awing Health District showed that most of the water borne diseases registered yearly in Awing are from these quarters that are not connected to the treated pipe born water supply line.

Faced with the above problem and coupled with the fact that the quality of springs in this area has never been assessed, the major objective of this research work was to evaluate the quality of some springs in Awing in order to provide information on the extent of contamination and the prevalence of water borne diseases in these areas. To achieve this objective, organoleptic, physicochemical, and microbiological parameters of the water samples were examined and correlated to the water borne diseases registered in the study area. This gave room for firm recommendations to be made on the proper management of the springs by the inhabitants to enhance good drinking water quality and better health conditions.

\section{Materials and Methods}

2.1. Site Descriptions. Awing is found in the grass field zone of Cameroon, precisely in Santa Subdivision of the Northwest Region of Cameroon (Figure 1). It is situated at about $21 \mathrm{~km}$ south-east of Bamenda town. Awing has a surface area of about $480 \mathrm{~km}^{2}$ and as of the year 2010 , its population density stood at 115.2 people $/ \mathrm{km}^{2}$. Located between latitudes $05^{\circ} 47^{\prime}$ and $06^{\circ} 00^{\prime}$ North of the equator and longitudes $10^{\circ} 10^{\prime}$ and $10^{\circ} 22^{\prime}$ East of the Greenwich Meridian, Awing has an elevation of about $1206 \mathrm{~m}$ above sea level. Its topography is troughlike, a low lying plain, surrounded by an extension of the volcanic chain of the Bambouto Mountain in the West, North, and East, hemmed by a network of hills. The highest point here is Mount Lefo (fourth highest mountain in Cameroon), with a height of $2550 \mathrm{~m}$ on whose northern flank is Lake Awing [10, 12].

2.2. Site Characteristics, Field Methods, and Sampling. Sampling was done in the months of December 2016 for the dry season and May 2017 for the rainy season. Three representative sites containing spring water sources were selected, based on the population density, agricultural practices, and the scarcity of pipe born water in the areas. The sites are Achialum (AC), Meupi (ME), and Ala'amiti (AL). Achialum spring is located on Longitude $10^{\circ} 13^{\prime} 56^{\prime \prime} \mathrm{E}$ and Latitude $05^{\circ} 50^{\prime} 39^{\prime \prime}$ $\mathrm{N}$, with an elevation of $1627 \mathrm{~m}$ above sea level. This spring is a natural groundwater outflow that responds well to any changes that occur in natural ecosystems with water volume increasing in the raining season and drastically reducing in the dry season. Meupi spring is located on Longitude $10^{\circ} 14^{\prime} 24.2^{\prime \prime} \mathrm{E}$ and Latitude $05^{\circ} 50^{\prime} 13.9^{\prime \prime} \mathrm{N}$, with an elevation of $1589 \mathrm{~m}$ above sea level. Ala'amiti spring is located on Longitude $10^{\circ} 14^{\prime} 35.8^{\prime \prime} \mathrm{E}$ and Latitude $05^{\circ} 52^{\prime} 37.8^{\prime \prime} \mathrm{N}$, with an elevation of $1756 \mathrm{~m}$ above sea level. Grass land vegetation mixed with patches of trees and raffia predominantly characterises the surroundings of all the springs sampled (Figure 2).

Water samples were collected following the grab sampling method. Sampling was done early in the morning, afternoon, and evening periods. Samples were collected the same day in order to better evaluate the quality of the water sources. Water samples were collected in plastic bottles of $1.5 \mathrm{~L}$ thoroughly cleaned and rinsed with the water to be sampled. Samples were then labelled and taken to the laboratory where preservation and analysis were done.

\subsection{Laboratory Analysis}

2.3.1. Organoleptic and Physicochemical Analysis. Organoleptic parameters were determined using the human senses. The appearance of the samples was determined by observing with the eyes. The characteristics of interest included the perceptible colour of the water, state of floating of the particles, and speed of flow. Odour was described by making use of the sense of smell either as being offensive or smelling. $\mathrm{pH}$ and temperature were measured in the field with a $\mathrm{pH} / \mathrm{T}$ meter (Pen type). Water turbidity was measured using a turbidimeter (DRT, 100B, MF scientific, Inc. model) by allowing a beam of light to be projected towards the tube in which the samples were contained. Electrical conductivity was measured using a conductimeter (Wissenschaftlich-Technische-Werkstätten = WTW model). Chloride content was measured using the argentometric method (silver nitrate titration). Total nitrogen exists in three forms, namely, nitrate-nitrogen $\left(\mathrm{NO}_{3}-\mathrm{N}\right)$, ammonium-nitrogen $\left(\mathrm{NH}_{4}{ }^{+}-\mathrm{N}\right)$, and organic-nitrogen (byproducts from living organisms). Ammonium-nitrogen and 


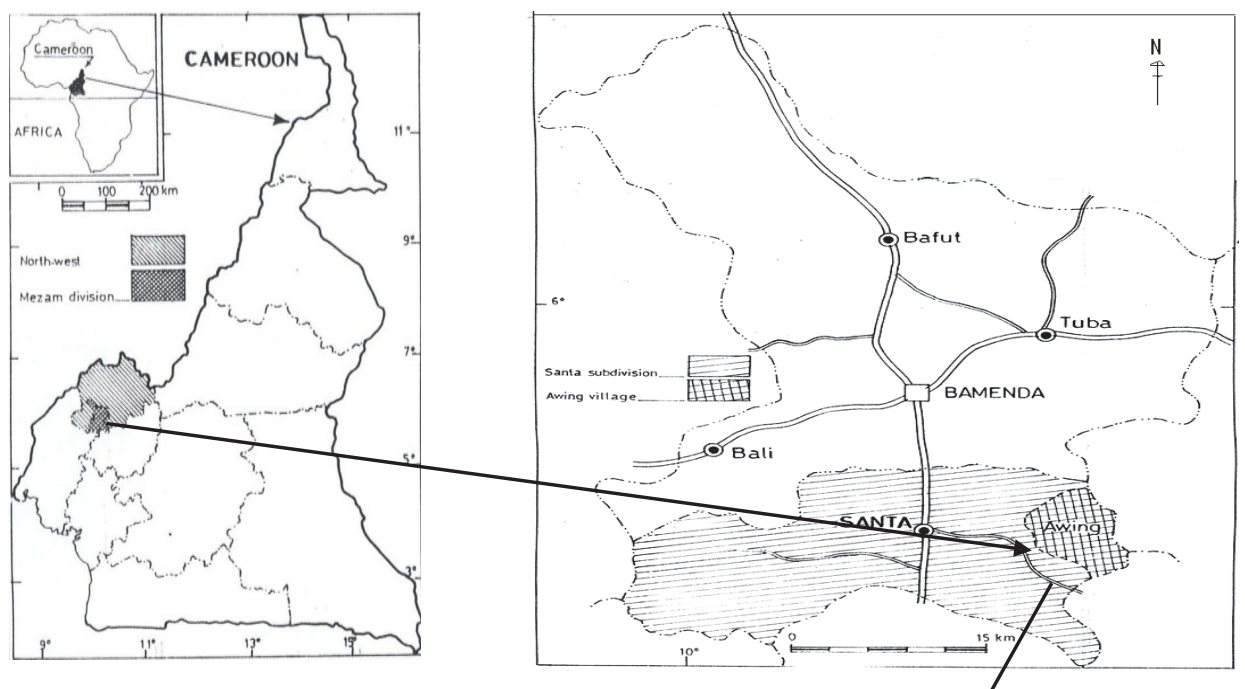

(a)

(b)
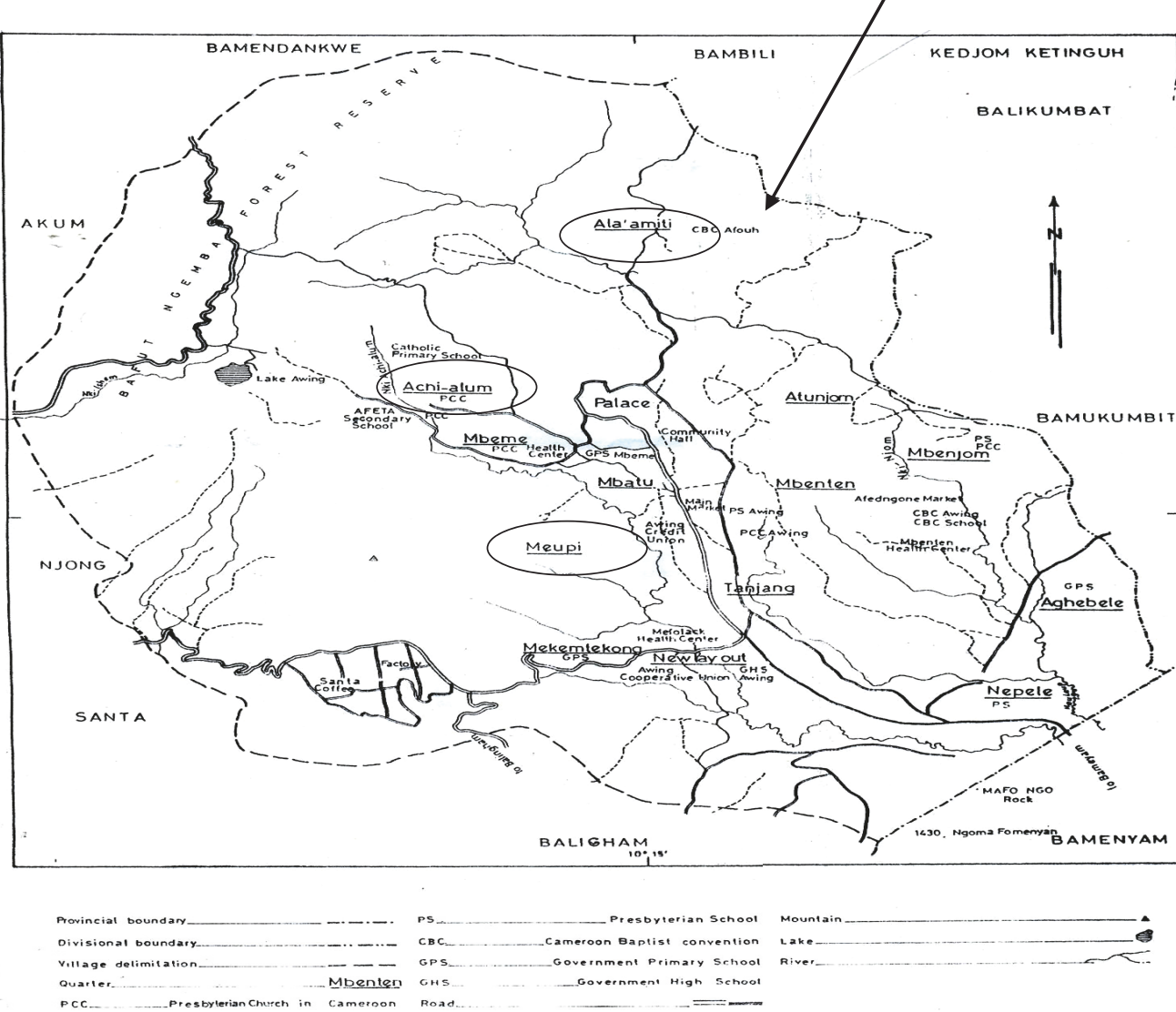

(c)

FIGURE 1: Map of study area. (a) Map of Cameroon showing Northwest and Mezam Division. (b) Map of Mezam Division showing Awing. (c) Map of Awing showing sampling sites (source: [10]).

nitrate-nitrogen were determined by Kjeildahl's distillation method. Phosphates were determined by UV-visible spectrophotometric analysis. The bicarbonates were determined by acid-base titration and sulphates by gravimetric analysis. $\mathrm{Ca}$ and $\mathrm{Mg}$ were determined by complexometric titration while $\mathrm{Na}$ and $\mathrm{K}$ were determined by flame photometry following methods described by Pauwels et al. [13].

2.3.2. Bacteriological Analysis. Two methods were used: the multiple tube fermentation technique or most probable 


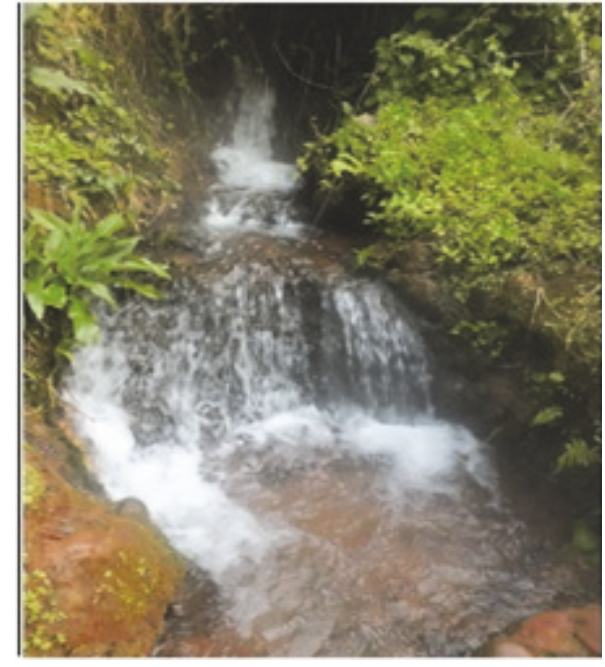

(a)

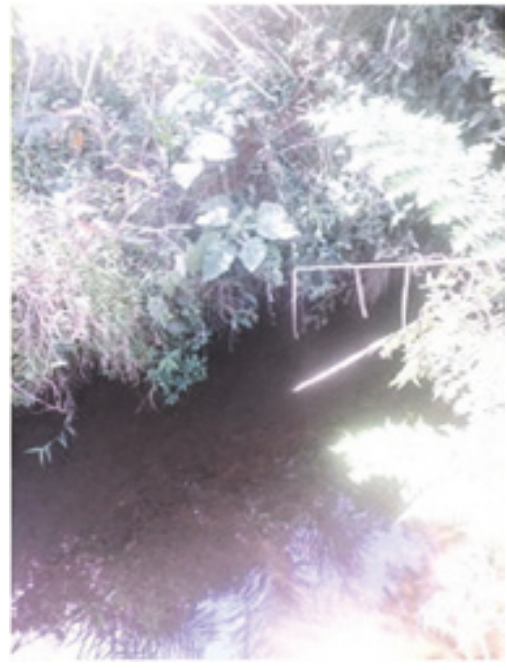

(b)

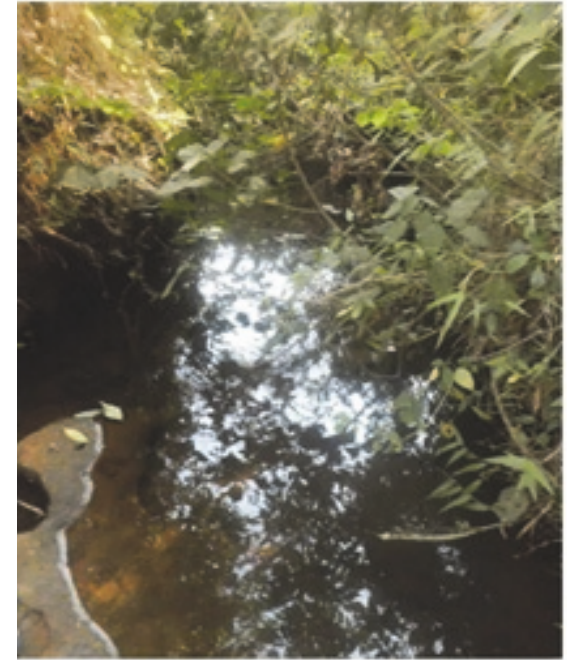

(c)

Figure 2: Sampled springs ((a) Achialum; (b) Meupi; (c) Ala’amiti).

number (MPN) technique for the presumptive determination of total coliforms and the standard count plate technique for determination of specific bacteria (Salmonella, Escherichia coli, Streptococcus, Proteus, and enterobacteria) as described by Cheesbrough [14]. In this technique a $100 \mathrm{~mL}$ water sample was distributed $(1 \mathrm{~mL}$ amount, $10 \mathrm{~mL}$ amount, and $50 \mathrm{~mL}$ amount) in bottles of sterile selective culture broth containing lactose and an indicator. After incubation, the number of bottles in which lactose fermentation with acid and gas production occurred was counted. The lactose is fermented by the coliforms in the water. With reference to probability tables, the most probable number of coliforms in the $100 \mathrm{~mL}$ water sample was estimated and the water category obtained.

2.4. Water Quality Index. The water quality index (WQI) model simplifies the presentation of results of an investigation related to a water body as it summarises in one value or concept a series of parameters analysed. A single WQI value makes information more easily and rapidly understood than a long list of numerical values for a large variety of parameters. More so, WQI also facilitates comparison between different sampling sites and events [15-18]. The following steps were used for determining the WQI [18]. In the first step, the unit weight $\left(W_{i}\right)$ for each water quality parameter was determined using the following formula:

$$
W_{i}=\frac{K}{S_{i}}
$$

where

$S_{i}$ is standard value of $i$ th parameter recommended by WHO;

$K$ is the proportionality constant which is calculated by using the following equation:

$$
K=\frac{1}{\left(\sum\left(1 / S_{i}\right)\right)}
$$

The inverse of the sum of inverses of standard parameters is used in order to make parameters expressed by large numbers to weigh less in the final formula (see (4)).

In the second step, quality rating or subindex $\left(q_{i}\right)$ was computed for each of the parameters using the expression

$$
q_{i}=\frac{V_{i}-V_{0}}{\left(S_{i}-V_{0}\right)} \times 100
$$

where

$V_{i}$ is estimated value of $i$ th parameter in the analysed water sample;

$V_{0}$ is ideal value of this parameter in pure water (it is zero for all parameters except $\mathrm{pH}=7.0$ and $\mathrm{TDO}=14.6 \mathrm{mg} / \mathrm{L}$ );

$S_{i}$ is recommended standard value of $i$ th parameter given by WHO.

In the final step, the overall WQI was calculated by using following formula:

$$
\mathrm{WQI}=\frac{\sum q_{i} W_{i}}{\sum W_{i}}
$$

2.4.1. Statistical Analysis. Paired sample Student's test ( $t$-test) was used to compare the results for each parameter in the dry and rainy seasons. Pearson's product moment correlation analyses were also performed between some selected water physicochemical parameters and bacteria content of the water samples. Analyses at $95 \%$ confidence level were used to determine the significant difference at $p \leq 0.05$. All statistical analyses were performed using SPSS Version 19.

\section{Results}

Results of organoleptic, physicochemical, and bacteriological analyses of Achialum (AC), Meupi (ME), and Ala'amiti (AL) springs are presented in Tables 1-5. Comments in the table follow the WHO drinking water standards. Results of 
TABLE 1: Results of organoleptic parameters.

\begin{tabular}{|c|c|c|c|c|}
\hline \multirow{2}{*}{ Samples } & \multicolumn{2}{|c|}{ Appearance } & \multicolumn{2}{|c|}{ Odour } \\
\hline & December & May & December & May \\
\hline $\mathrm{AC}$ & Colourless with tiny debris & Colourless with tiny debris & Odourless & Odourless \\
\hline ME & Colourless with tiny debris & Colourless with tiny debris & Odourless & Odourless \\
\hline $\mathrm{AL}$ & Colourless with tiny debris & Colourless with tiny debris & Odourless & Odourless \\
\hline WHO limit & & Clean, clear, colourless, and odourless & & \\
\hline
\end{tabular}

TABLE 2: Results of physical parameters.

\begin{tabular}{|c|c|c|c|c|c|c|c|c|}
\hline \multirow{2}{*}{ Sample } & \multicolumn{2}{|c|}{$\mathrm{pH}$} & \multicolumn{2}{|c|}{$T\left({ }^{\circ} \mathrm{C}\right)$} & \multicolumn{2}{|c|}{$\mathrm{EC}\left(\mathrm{mS} \mathrm{cm}^{-1}\right)$} & \multicolumn{2}{|c|}{$\mathrm{Tu}$ (NTU) } \\
\hline & December & May & December & May & December & May & December & May \\
\hline $\mathrm{AC}$ & 6.5 & 7.0 & 21.5 & 23.8 & 0.08 & 1.6 & 0.3 & 2.0 \\
\hline ME & 6.9 & 7.2 & 19.9 & 20.9 & 0.03 & 0.04 & 1.6 & 6.6 \\
\hline $\mathrm{AL}$ & 6.5 & 6.7 & 20.6 & 21.2 & 0.03 & 0.04 & 1.9 & 3.4 \\
\hline WHO limit & \multicolumn{2}{|c|}{$6.5-8.5$} & \multicolumn{2}{|c|}{$15-25$} & \multicolumn{2}{|c|}{2} & \multicolumn{2}{|c|}{$0.1-5$} \\
\hline
\end{tabular}

$T=$ temperature; $\mathrm{EC}=$ electrical conductivity; $\mathrm{Tu}=$ turbidity, and NTU = nephelometric turbidity units.

Student's $t$-test analyses showed that no significant differences $(p>0.05)$ existed between most of the parameters in December 2016 and May 2017 except $\mathrm{NH}_{4}-\mathrm{N}$ and $\mathrm{SO}_{4}{ }^{2-}$ which were significantly different $(p<0.05)$ between the two sampling seasons. Significant positive correlations were recorded between some water parameters: electrical conductivity (EC) and $\mathrm{Ca}^{2+}(r=1.000, p<0.01)$, EC and $\mathrm{Mg}^{2+}$ $(r=1.000, p<0.01)$, turbidity and enterobacteria $(r=0.997$, $p<0.05), \mathrm{Ca}^{2+}$ and $\mathrm{Mg}^{2+}(r=0.999, p<0.05), \mathrm{Ca}^{2+}$ and $\mathrm{Na}^{+}(r=1.000, p<0.01), \mathrm{HCO}_{3}{ }^{-}$and enterobacteria $(r=0.999, p<0.05), \mathrm{HCO}_{3}{ }^{-}$and Streptococcus $(r=1.00$, $p<0.01)$, and Shigella and Salmonella $(r=0.997, p<0.05)$.

\section{Discussion}

Results of organoleptic parameters showed that all the water samples were colourless with tiny debris and also odourless (Table 1). This may be due to the fact that these springs are naturally filtered as they flow vertically from underground to the surface. Debris in the water samples may be as a result of infiltration of solid particles as the water flows through the soil surface. Ideally, safe drinking water should be clean and clear, as well as colourless and odourless. Colour, odour, and taste in drinking water are generally indicators of other contaminants [2]. This implies that these sources of water will require extra physical treatment techniques such as filtration to render it potable.

The $\mathrm{pH}$ of all the samples ranged from 6.5 to 7.2 with AL spring having the lowest mean value and ME spring the highest mean value (Table 2). These $\mathrm{pH}$ values fell within WHO acceptable limit (6.5-8.5), meaning that there was no case of acidity or alkalinity which could be accompanied by adverse consequences. The $\mathrm{pH}$ interval given by the $\mathrm{WHO}$ guidelines is mostly linked to the preservation of pipes against corrosion. Therefore, if water is taken by people with plastic bottles/containers, the $\mathrm{pH}$ issue has relatively limited importance.
The temperature of all the samples ranged from $19.9^{\circ} \mathrm{C}$ to $23.8^{\circ} \mathrm{C}$ with $\mathrm{AC}$ spring having the highest mean value and ME spring the lowest mean value (Table 2). The lower temperatures recorded in the dry season compared to the rainy season may be due to the fact that the climatic conditions of the area permit a general decrease in temperature during the early morning hours of the dry season as compared to the rainy season. All the values fell within $\mathrm{WHO}$ acceptable limit $\left(15-25^{\circ} \mathrm{C}\right)$.

The electrical conductivity levels of all the samples ranged from 0.03 to $1.6 \mathrm{mS} / \mathrm{cm}$ (Table 2). These values were quite low compared to the WHO limit of $2 \mathrm{mS} / \mathrm{cm}$ and were within limits, suggesting the occurrence of low mineralized water with very little dissolved solids [19]. Therefore, there was no contamination from dissolved solids. The positive correlation observed between EC and $\mathrm{Ca}^{2+}(r=1.000, p<0.01)$ and between EC and $\mathrm{Mg}^{2+}(r=1.000, p<0.01)$ could be explained by the fact that $\mathrm{Ca}^{2+}$ and $\mathrm{Mg}^{2+}$ ions are usually the most concentrated cations in natural waters that contribute to the electrical conductivity of water.

The turbidity of all the samples ranged from 0.3 to 6.6 NTU as shown in Table 2. Comparing these results to the WHO limit of $5 \mathrm{NTU}$, it turned out that AC and AL springs were within the acceptable limits while ME spring was slightly turbid in April. This implies that the amount of suspended solids was quite small in the water samples. The most worrying effect of turbidity is its contribution in bacteria and viruses' growth and also its capacity to protect them against disinfection [20]. For this reason, the bacteriological quality of ME spring could be doubtful while $\mathrm{AC}$ and AL springs present no risk associated with turbidity. A positive correlation was also observed between turbidity and enterobacteria $(r=0.997, p<0.05)$ suggesting that their growth is favoured by the presence of suspended solids in water.

The mineralization of water is dominated by eight ions usually called the major ions. They are calcium, magnesium, 


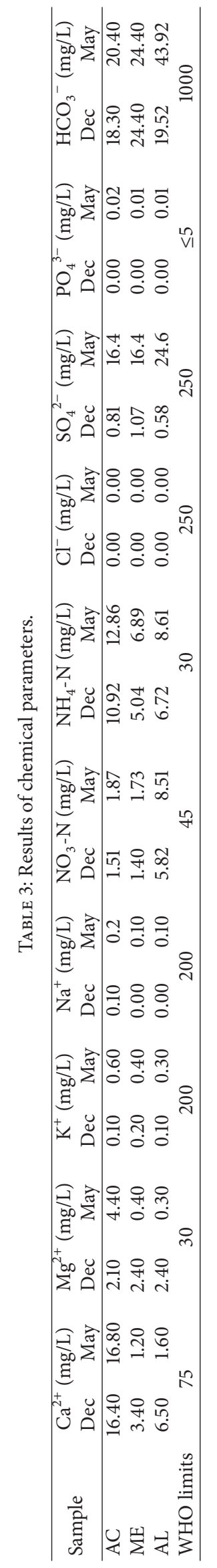


TABLE 4: Results of bacteriological analysis (most probable number of faecal coliforms).

\begin{tabular}{|c|c|c|c|c|c|c|c|c|c|c|}
\hline \multirow{3}{*}{$\begin{array}{l}\text { Volume of samples in each bottle } \\
\text { Sample }\end{array}$} & \multirow{2}{*}{\multicolumn{2}{|c|}{$50 \mathrm{~mL}$}} & \multirow{2}{*}{\multicolumn{2}{|c|}{$10 \mathrm{~mL}$}} & \multirow{2}{*}{\multicolumn{2}{|c|}{$1 \mathrm{~mL}$}} & \multicolumn{4}{|c|}{ Most probable } \\
\hline & & & & & & & \multicolumn{2}{|c|}{ Mean count } & \multicolumn{2}{|c|}{ Category } \\
\hline & Dec & May & Dec & May & Dec & May & Dec & May & Dec & May \\
\hline $\mathrm{AC}$ & 1 & 1 & 4 & 3 & 4 & 2 & 49 & 14 & $\mathrm{C}$ & $\mathrm{C}$ \\
\hline $\mathrm{ME}$ & 1 & 1 & 4 & 4 & 3 & 2 & 42 & 20 & $\mathrm{C}$ & $\mathrm{C}$ \\
\hline $\mathrm{AL}$ & 1 & 1 & 3 & 4 & 5 & 1 & 40 & 17 & $\mathrm{C}$ & $\mathrm{C}$ \\
\hline WHO limits & \multicolumn{6}{|c|}{0} & \multicolumn{2}{|c|}{0} & \multicolumn{2}{|c|}{ A } \\
\hline
\end{tabular}

$\mathrm{A}=$ excellent; $\mathrm{B}=$ low risk, acceptable; $\mathrm{C}$ = high risk, unacceptable; $\mathrm{D}$ = grossly polluted.

TABLE 5: Results of bacteriological analysis (specific microbes identified per colony forming unit, CFU/100 mL).

\begin{tabular}{|c|c|c|c|c|c|c|c|c|c|c|c|c|}
\hline \multirow{2}{*}{ Sample } & \multicolumn{2}{|c|}{ Enterobacteria } & \multicolumn{2}{|c|}{ E. coli } & \multicolumn{2}{|c|}{ Streptococcus } & \multicolumn{2}{|c|}{ Salmonella } & \multicolumn{2}{|c|}{ Shigella } & \multicolumn{2}{|c|}{ Staphylococcus } \\
\hline & Dec & May & Dec & May & Dec & May & Dec & May & Dec & May & Dec & May \\
\hline $\mathrm{AC}$ & 450 & 100 & 150 & 65 & 370 & 300 & 150 & 35 & 100 & 05 & 00 & 70 \\
\hline $\mathrm{ME}$ & 200 & 400 & 120 & 200 & 300 & 600 & 50 & 120 & 10 & 04 & 00 & 100 \\
\hline $\mathrm{AL}$ & 100 & 150 & 60 & 100 & 00 & 50 & 50 & 30 & 02 & 03 & 50 & 60 \\
\hline WHO limits & & & & & & 0 & & & & & & \\
\hline
\end{tabular}

E. coli: Escherichia coli.

sodium and potassium, chloride, sulphate, nitrate, and bicarbonate.

Calcium and magnesium levels of all the samples ranged from 1.2 to $16.8 \mathrm{mg} / \mathrm{L}$ and 0.3 to $4.4 \mathrm{mg} / \mathrm{L}$, respectively (Table 3). These values were below the WHO limit of $75 \mathrm{mg} / \mathrm{L}$ for calcium and $30 \mathrm{mg} / \mathrm{L}$ for magnesium. Low $\mathrm{Ca}^{2+}$ and $\mathrm{Mg}^{2+}$ contents may be due to their low content in rocks of the study area. Similar results were reported by Wirmvem et al. [19], working on the hydrochemistry of shallow groundwater and surface water in the Ndop plain, Northwest Cameroon, and Ghazali and Zaid [20], working on the physicochemical and bacteriological quality of spring waters of Ain Salama-Jerri (area of Meknes, Morocco). The positive correlation between $\mathrm{Ca}^{2+}$ and $\mathrm{Mg}^{2+}(r=0.999, p<0.05)$ and $\mathrm{Na}^{+}(r=$ $1.000, p<0.01)$ was probably due to their common origin. From the results obtained, no contamination by calcium and magnesium was observed and consequently, the water is soft [21]. However, the low content of both elements need to be compensated through other means as they are essential for humans and a deficiency in both may lead to unhealthy bones and teeth in the long run, have negative effects on the nervous system, the digestive system, and may also cause muscles' cramps and cardiovascular mortality in the shorter term [2].

Potassium and sodium levels varied from 0.1 to 0.6 and 0.0 to $0.2 \mathrm{mg} / \mathrm{L}$, respectively (Table 3 ). The concentrations were very low compared to the WHO limit of $200 \mathrm{mg} / \mathrm{L}$ for both potassium and sodium. Low $\mathrm{K}^{+}$may be due to its low geochemical mobility [19]. Sodium in water generally comes from the leaching of geological formations containing sodium chloride as well as rock salt decomposition like sodium and aluminium silicates [22]. So, low $\mathrm{Na}^{+}$is probably due to low $\mathrm{NaCl}$ as well as low sodium and aluminium silicates in the soils of the study area. Thus, there was no potassium and sodium contamination. These results are similar to those obtained by Wirmvem et al. [19]
TABLE 6: Water classification for agricultural purposes.

\begin{tabular}{lc}
\hline SAR & Water class (for agricultural purposes) \\
\hline $0-10$ & Excellent \\
$10-18$ & Good \\
$18-26$ & Fair \\
$>26$ & Poor \\
\hline
\end{tabular}

Chloride was nondetectable in all the samples. This was possibly due to the nature of the soil [22]. So, the water sources were of good quality with respect to chloride content.

The classification of water for agricultural purposes is based on specific conductance expressed as Total Dissolved Solids (TDS), sodium content, and boron concentration. Sodium content is the most important element used to determine water quality for the basis of agriculture because it is the reaction of sodium with soil that determines soil's permeability. To determine the suitability of water for agricultural purposes, a formula called the sodium adsorption ratio (SAR) was used [6]:

$$
\mathrm{SAR}=\frac{\left[\mathrm{Na}^{+}\right]}{\sqrt{ }\left[\mathrm{Ca}^{2+}+\mathrm{Mg}^{2+}\right]} .
$$

The SAR was $0.034,0.026$, and 0.022 for AC, ME, and AL springs, respectively. So from Table 6, all the springs fell within the excellent range (0-10), indicating that the water is very good for agricultural purposes.

Bicarbonates are responsible for water alkalinity. Analysis showed that the samples had bicarbonate ranging between 18.3 and $43.92 \mathrm{mg} / \mathrm{L}$, which were below the WHO value of $1000 \mathrm{mg} / \mathrm{L}$ (Table 3 ). The presence of $\mathrm{HCO}_{3}{ }^{-}$suggests its possible igneous origin [19]. $\mathrm{HCO}_{3}{ }^{-}$may also originate from the dissolution of carbon dioxide and its low content is possibly due to the process of autopurification of water. Thus 
TABLE 7: Water quality classification based on WQI.

\begin{tabular}{lcc}
\hline WQI level & Water quality & Grading \\
\hline $0-25$ & Excellent & $\mathrm{A}$ \\
$25-50$ & Good & $\mathrm{B}$ \\
$51-75$ & Poor & $\mathrm{C}$ \\
$76-100$ & Very poor & $\mathrm{D}$ \\
$>100$ & Unfit for drinking purpose & $\mathrm{E}$ \\
\hline
\end{tabular}

bicarbonate levels presented no contamination of the water samples. The positive correlation between $\mathrm{HCO}_{3}{ }^{-}$and enterobacteria $(r=0.999, p<0.05)$ and between $\mathrm{HCO}_{3}{ }^{-}$and Streptococcus $(r=1.00, p<0.01)$ suggests that water with high alkalinity favours their growth.

Sulphate levels ranged from 0.58 to $24.6 \mathrm{mg} / \mathrm{L}$ and were insignificant compared to the WHO value of $250 \mathrm{mg} / \mathrm{L}$ (Table 3). Excess sulphate can cause adverse gastrointestinal problems. Its presence in water can be as a result of acid rain, the dissolution of evaporated sedimentary rocks, and the use of artificial fertilizer and detergents [23, 24].

The concentration of $\mathrm{NO}_{3}-\mathrm{N}$ in the samples ranged from 1.4 to $8.51 \mathrm{mg} / \mathrm{L}$ (Table 3 ) which when compared to the WHO limit of $50 \mathrm{mg} / \mathrm{L}$ fell well below. The slight increase in the amount of $\mathrm{NO}_{3}-\mathrm{N}$ in the month of May 2017 (rainy season) could be a consequence of leaching from natural vegetation and anthropogenic sources like the use of organic fertilizers washed into the springs by runoff $[2,4]$. Elevated nitrate contents can cause the disease known as "blue-baby" or methemoglobinemia [24, 25]. Temgoua [25] also reported nitrate content in water ranging between 0.9 and $3.5 \mathrm{mg} / \mathrm{L}$. Thus, the springs were free of nitrate contamination.

The concentration of $\mathrm{NH}_{4}-\mathrm{N}$ in the samples ranged from 5.04 to $12.86 \mathrm{mg} / \mathrm{L}$ and was below the limit of $30 \mathrm{mg} / \mathrm{L}$ prescribed by WHO (Table 3). Its presence in water is a possible indicator of bacterial, sewages, and animal wastes pollution [2]. Similar results were reported by Njoyim et al. [4] and Njoyim et al. [5] working on water samples elsewhere in Cameroon. High values of $\mathrm{NH}_{4}-\mathrm{N}$ recorded throughout the study period may have resulted from pollution with animal or human organic matter and could indicate on one hand, high mineralization of water, and on the other hand, an increase in organic matter loads, thus indicating poor water quality. $\mathrm{NH}_{4}-\mathrm{N}$ contents in the samples increased significantly from December to May $(p<0.05)$ suggesting its leaching from the above sources into the spring waters.

Phosphate were very low $(<0.03 \mathrm{mg} / \mathrm{L})$ in all samples in both months and this can be due to its sorption on organic colloids found in water. Wirmvem et al. [19] also reported the absence of phosphate in groundwater in the Ndop plain. Thus, there was no health risk associated with ammonium and phosphate in the springs of the study area.

4.1. Suitability of Water for Drinking Purposes Using Water Quality Index (WQI). The overall quality of the spring water body was assessed by using the WQI level given in Table 7 $[17,18]$.
Results of WQI for the springs analysed are presented in Table 8 . The combined effect of physicochemical parameters gave water quality indices of 27.44, 51.71, and 26.78 for AC, $\mathrm{ME}$, and AL respectively. Using Table 7, AC and AL springs were of good quality while the ME spring was of poor quality. In a nutshell, all the springs were fit for human use as indicated by Pratap et al. [17]. WQI may not carry enough information about the real quality situation of water since the eclipsing or overemphasizing of a single bad parameter value can give misleading information about the water quality [26]. A single number cannot tell the whole story of water quality; there are many other water quality parameters that are not included in the index and thus, other parameters need to be examined before a conclusion can be made about the overall water quality.

Results of bacteriological quality of the analysed water samples are presented in Tables 4 and 5. Analysis revealed the presence of faecal coliforms in all the water samples with mean counts ranging between 40 and 49 MPN in the month of December 2016 and between 14 and $20 \mathrm{MPN}$ in May 2017. Based on WHO classification, all the spring waters presented a high risk and were therefore unacceptable falling under category C [2]. Further analysis of the water samples also revealed the presence of pathogenic bacteria amongst which there are enterobacteria, E. coli, Streptococcus, Salmonella, Shigella, and Staphylococcus. Colonies of bacteria in $100 \mathrm{~mL}$ of the analysed water samples gave high numbers as shown in Table 5. The presence of faecal coliforms suggests contamination by human or animal faeces. Similar high faecal coliform counts have also been reported elsewhere in Cameroon by Temgoua [25], Wirmvem et al. [27], Njoyim et al. [4], Njoyim et al. [5], and Njoyim et al. [28]. The variation of the most probable number of coliforms can possibly be due to the influence of rain. The bad quality of this water can be due to poor hygiene and sanitation $[4,5,29,30]$. The water sources are located in places with a high rate of pollution coming from the toilets and farms resulting in the infiltration of pathogenic microorganisms into the water. The positive correlation $(r=0.997, p<0.05)$ between Shigella and Salmonella suggests their common origin. The presence of faecal coliforms and pathogenic bacteria showed that the analysed springs were of bad quality. Thus, consumption of the water exposes the local population to water borne diseases such as typhoid, dysentery, and diarrhea.

Data on water borne diseases obtained from the Awing Health District is presented on Figure 3. Figure 3 shows that water borne diseases are still a major problem in the study area with typhoid levels increasing for the past four years. Results of bacteriological analysis revealed that the water sources were highly contaminated with bacteria and this is confirmed by the number of water borne diseases the populations of the study area are suffering from.

\section{Conclusions}

This study was aimed at evaluating the quality of some springs in the Awing Community, Northwest Cameroon. Results showed that the springs were slightly acidic to neutral with 


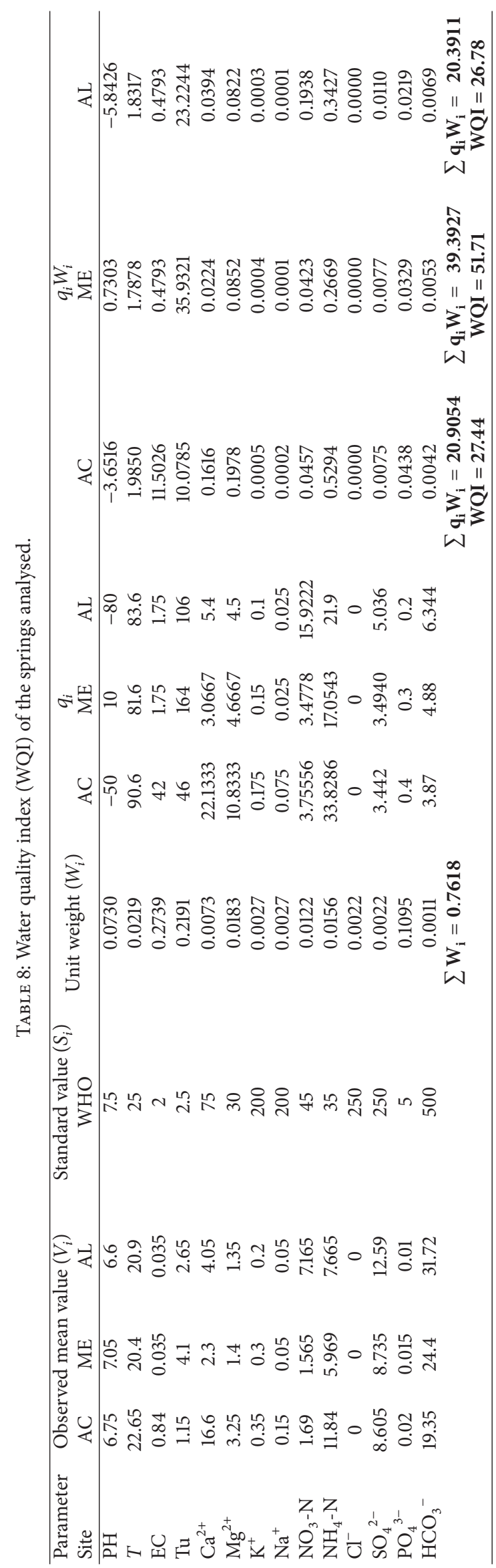




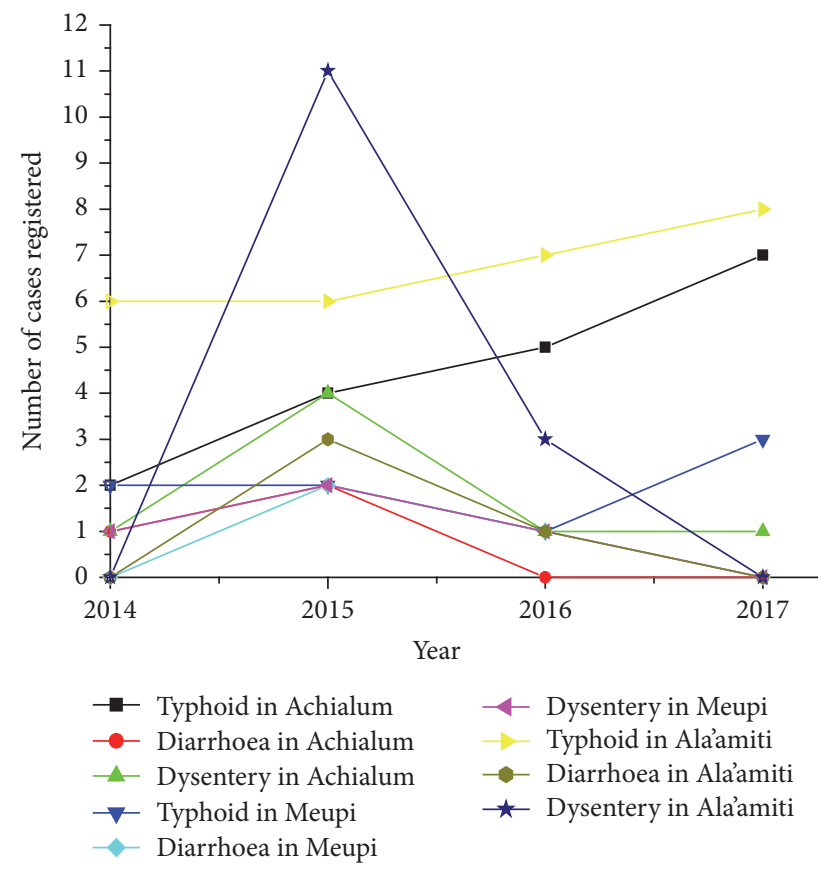

FIGURE 3: Water borne diseases registered in the sampled areas for the past four years (source: Awing Health District).

$\mathrm{pH}$ ranging between 6.5 and 7.2. Electrical conductivity and turbidity were also very low suggesting the occurrence of low mineralized and clear to slightly turbid water. All the essential ions had low concentrations and fell below WHO limits. The sodium adsorption ratio was $0.034,0.026$, and 0.022 for Achialum, Meupi, and Ala'amiti springs, respectively, indicating that all the springs were very good for agricultural purposes. The results of water quality index showed that Achialum and Ala'amiti springs were of good quality while Meupi spring was of poor quality. Water quality index may not carry enough information about the real quality situation since the eclipsing or overemphasizing of a single bad parameter value can give misleading information about the water quality. Concerning the bacteriological aspect, all the samples had very high levels of faecal coliforms and pathogenic bacteria such as enterobacteria, E. coli, Streptococcus, Salmonella, Shigella, and Staphylococcus that justified the bad quality of the spring waters and high rate of water borne diseases recorded in the area. This bad water quality could be associated with poor hygiene as well as poor source management and farming activities [30]. On a general view, the springs presented little or no risk on health as far as organoleptic and physicochemical parameters were concerned. These results conform to those of Malakootian and Dowlatshahi [30] who indicated that the quality of each chemical parameter in drinking water wells of Zarand plain was within permissible limit and did not exceed neither the Iran's standards nor WHO guidelines. The great worry came from bad bacteriological quality not meeting the WHO standards for drinking water. Thus consumption of the water exposes the local population to water borne diseases such as typhoid, dysentery, and diarrhea as already indicated by public health information. Thus, the population of the study area is called upon to implement home water treatment methods such as boiling, filtration, solar disinfection, or chlorination prior to consumption.

\section{Conflicts of Interest}

The authors declare that there are no conflicts of interest regarding the publication of this article.

\section{Acknowledgments}

The authors are grateful to the water management authorities and health workers in Awing for providing the necessary information needed to accomplish this work.

\section{References}

[1] L. P. Li, A. Byleveld, and W. Smith, "Assessment of chemical quality ofdrinking water," in Drinking Water Quality Assessment, B. H. Ismaili, A. Shabani, and S. Abduli, Eds., pp. 142-145, Tetova Region science publication, Tetova, 2009.

[2] World Health Organization (WHO), Guidelines for DrinkingWater Quality, 4th edition, 2011.

[3] J. Afiukwa and A. Eboatu, "Analysis of spring water quality in Ebonyi South Zone and its health impact," American Journal of Scientific and Industrial Research, vol. 4, no. 2, pp. 231-237, 2013.

[4] E. B. T. Njoyim, N. A. Mofor, M. L. F. Niba, and J. Sunjo, "Physicochemical and bacteriological quality assessment of the Bambui community drinking water in the North West Region of Cameroon," African Journal of Environmental Science and Technology, vol. 10, no. 6, pp. 181-191, 2016.

[5] E. B. T. Njoyim, T. R. Menga, N. A. Mofor, F. B. Nchofua, and I. K. Njoyim, "Evaluation of surface and ground water quality in the Bangante municipality-West Cameroon," International Journal of Research and Reviews in Applied Sciences, vol. 28, no. 2, pp. 53-64, 2016.

[6] S. I. Ibeneme, L. N. Ukiwe, A. G. Essien et al., "Assessment of the Chemical Characteristics of a Spring Water Source at Ife-Owutu, Ezinihite-Mbaise, Southeastern Nigeria," American Journal of Engineering Research, vol. 2, no. 10, pp. 282-290, 2013.

[7] A. Haile Reda, "Assessment of Physicochemical Quality of Spring Water in Arbaminch, Ethiopia," Journal of Environmental Analytical Chemistry, vol. 02, no. 05, 2015.

[8] A. Wolanin and M. Zelazny, "Seasonal changes in spring water chemistry in the Chochołowski and Kościeliski stream catchments (Tatra Mts.) in 2009," in Water in the geographical study, T. Ciupa and R. Suligowski, Eds., pp. 339-347, Instytut Geografii Uniwersytetu Jana Kochanowskiego, Kielce, 2010.

[9] United Nations International Children Emergency Fund (UNICEF), Water Quality Assessment and Monitoring, Supply Division, 2010.

[10] "Ndong Awing Cultural and Development Association (NACDA)," Archives, 2010.

[11] E. M. Nyambod and H. Nazmul, "Integrated Water Resources Management and Poverty Eradication -Policy Analysis of Bangladesh and Cameroon," Journal of Water Resource and Protection, vol. 02, no. 03, pp. 191-198, 2010.

[12] P. Apongnde, The people of Awing, North West Cameroon, Pacific Print, Yaounde-Cameroon, 1st edition, 2014. 
[13] J. Pauwels, E. van Ranst, M. Verloo, and A. D. Mvondo-Ze, Manuel de laboratoire de pedologie. Methodes d'analyses de sols et de plantes, equipement, gestion de stocks de verrerie et de produits chimiques, Publications Agricoles, AGCD, Bruxelles, Belgium, 1992.

[14] M. Cheesbrough, Medical Laboratory Manual for Tropical Countries Volume II: Microbiology, Tropical Health Technology, New York, NY, USA, 1994.

[15] S. Tyagi, P. Singh, B. Sharma, and R. Singh, "Assessment of Water Quality for Drinking Purpose in District Pauri of Uttarakhand, India," Applied Ecology and Environmental Sciences, vol. 2, no. 4, pp. 94-99, 2014.

[16] S. Dipu, S. Chitralekha, R. Saha, and C. S. Rakesh, "Ground Water Quality Index of Howrah, the Heritage City of West Bengal, India," Applied Ecology and Environmental Sciences, vol. 3, no. 1, pp. 5-10, 2015.

[17] K. P. Pratap, B. P. Rahas, and K. D. Prasant, "Assessment of Water Quality Index of River Salandi at Hadagada Dam and Its Down Stream upto Akhandalmani," American Journal of Water Resources, vol. 4, no. 2, pp. 44-53, 2016.

[18] E. Inam, G. G. Inoh, N. O. Offiong, and B. B. Etim, "Physicochemical Characteristics and Health Risk Assessment of Drinking Water Sources in Okoroette Community, Eastern Coast of Nigeria," American Journal of Water Resources, vol. 5, no. 1, pp. 13-23, 2017.

[19] J. W. Mengnjo, O. Takeshi, Y. F. Wilson et al., "Hydrochemistry of shallow groundwater and surface water in the Ndop plain, North West Cameroon," African Journal of Environmental Science and Technology, vol. 7, no. 6, pp. 518-530, 2013.

[20] D. Ghazali and A. Zaid, "Etude de la qualite physico-chimique et bacteriologique des eaux de la source Ain Salama-Jerri (region de Meknes-Maroc)," Larhyss Journal, vol. 12, pp. 25-36, 2013.

[21] M. Lagnika, M. Ibikounle, J. C. Montcho, V. D. Wotto, and N. G. Sakiti, "Caractéristiques physico-chimiques de l'eau des puits dans la commune de Pobè (Bénin, Afrique de l'ouest)," Journal of Applied Biosciences, vol. 79, no. 0, p. 6887, 2014.

[22] M. L. Belghiti, "Study of the quality physico-chimical and bacteriological and groundwater of plio-quaternary ribbon in the region of Meknès (Morocco)," Larhyss Journal, vol. 14, p. 34, 2013.

[23] A. Abboudi, H. Tabyaoui, F. El Hamichi, L. Benaabidate, and A. Lahrach, "Etude de la qualité physico-chimique et contamination métallique des eaux de surface du bassin versant de Guigou, Maroc," European Scientific Journal, vol. 10, pp. 18577881, 2014.

[24] P. Jain, J. D. Sharma, D. Sohu, and P. Sharma, "Chemical analysis of drinking water of villages of Sanganer Tehsil, Jaipur District," International Journal of Environmental Science and Technology, vol. 2, no. 4, pp. 373-379, 2006.

[25] E. Temgoua, "Chemical and Bacteriological Analysis of Drinking Water from Alternative Sources in the Dschang Municipality, Cameroon," Journal of Environmental Protection, vol. 02, no. 05, pp. 620-628, 2011.

[26] T. Shweta, S. Bhavtosh, S. Prashant, and D. Rajendra, "Water Quality Assessment in Terms of Water Quality Index," American Journal of Water Resources, vol. 1, no. 3, pp. 34-38, 2013.

[27] M. J. Wirmvem, W. Y. Fantong, E. R. Wotany, O. Takeshi, and S. N. Ayonghe, "Sources of bacteriological contamination of shallow groundwater and health effects in Ndop plain, Northwest Cameroon," Journal of Environmental Science and Water Resources, vol. 2, pp. 127-132, 2013.
[28] E. B. T. Njoyim, F. B. Nchofua, N. A. Mofo, and Y. T. Djoko, "Contrôle de la qualité des eaux domestiques dans le village Babessi au Nord-Ouest Cameroun," International Journal of Biological and Chemical Sciences, vol. 10, no. 3, p. 1382, 2016.

[29] M. Malakootian and J. Nouri, "Chemical Variations of Ground Water Affected by the Earthquake in bam region," International Journal of Environmental Research, vol. 4, no. 3, pp. 443-454, 2010.

[30] M. Malakootian and S. Dowlatshahi, "Variations of chemical quality for drinking water sources in Zarand plain," Journal of Environmental Health Science and Engineering, vol. 4, no. 4, pp. 257-262, 2007. 

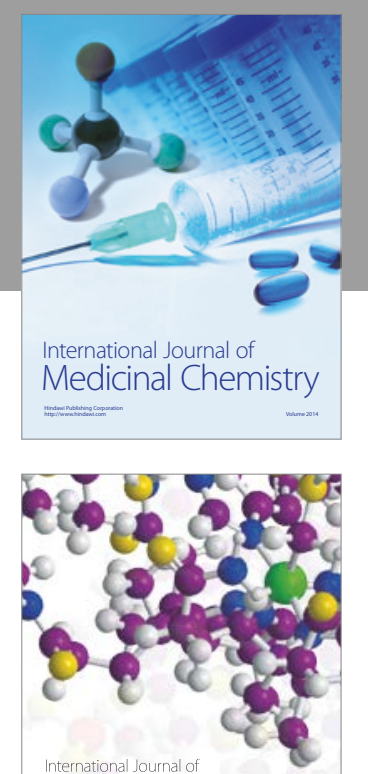

Carbohydrate Chemistry

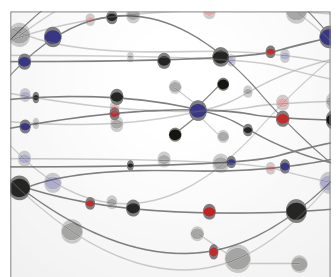

The Scientific World Journal
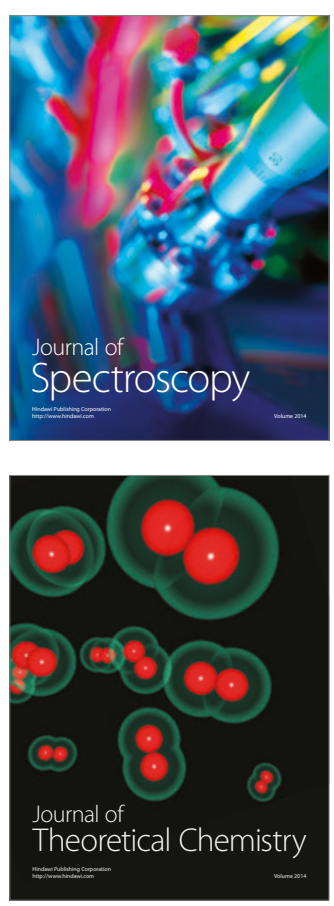
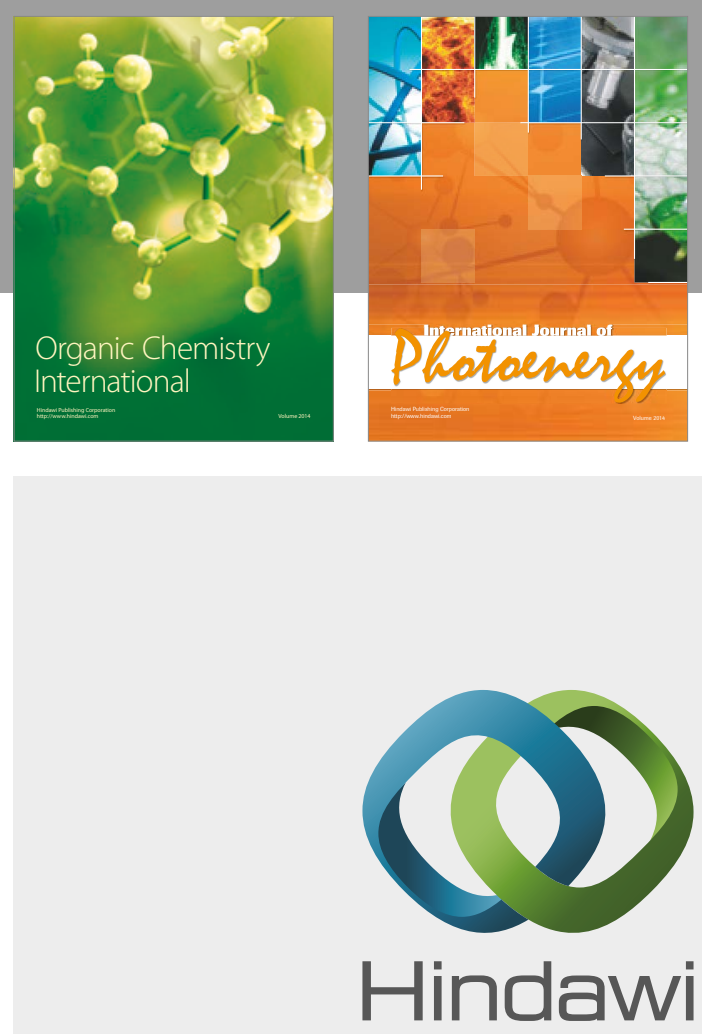

Submit your manuscripts at

https://www.hindawi.com

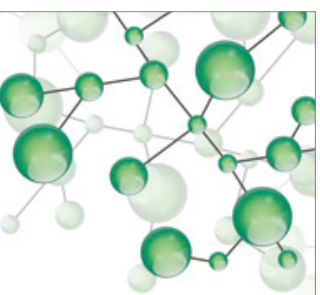

International Journal of

Inorganic Chemistry

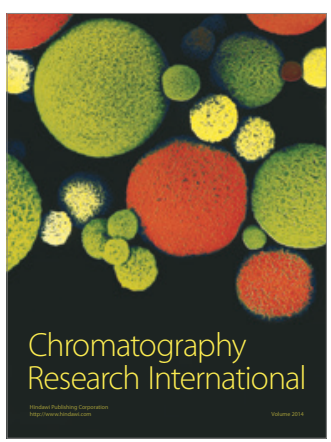

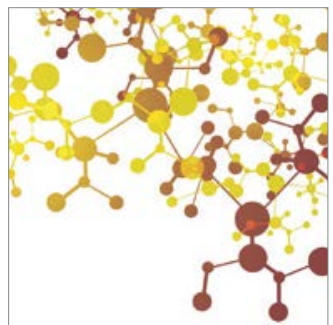

Applied Chemistry
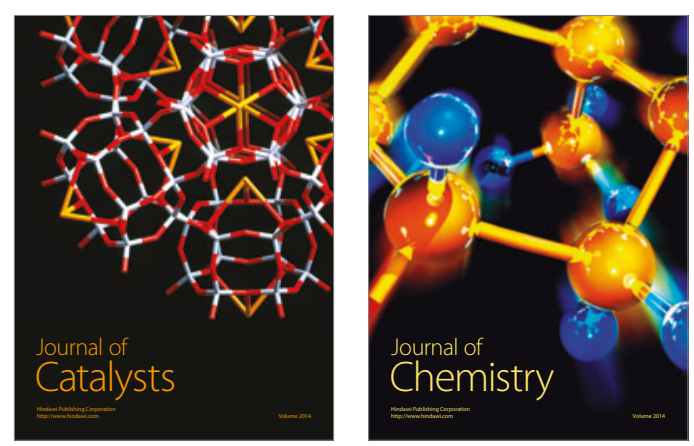
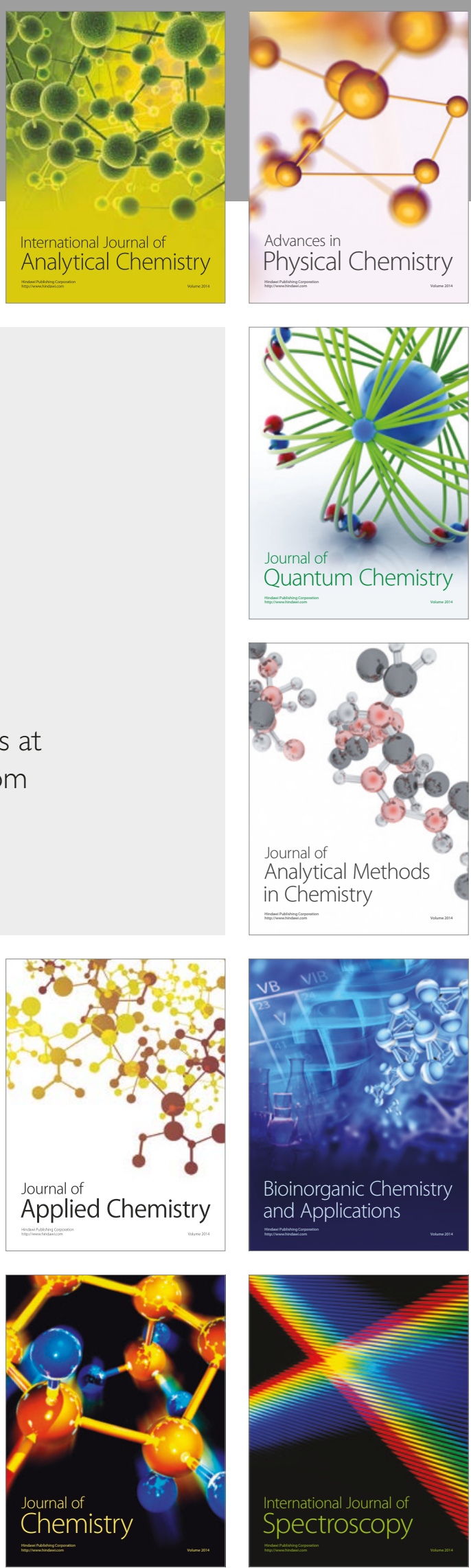